\title{
Karakteristik Termal dan Fungsionalitas Komposit Silika Sekam Padi dengan Aspal
}

\author{
Deafani Wahyu Ardaniswari ${ }^{1(\mathrm{a})^{*}}$, Josalina $^{(\mathrm{b})}$, Hana Haritsah $^{(\mathrm{c})}$, Simon \\ Sembiring ${ }^{(\mathrm{d})}$ \\ (1) Jurusan Fisika, FMIPA, Universitas Lampung, Bandar Lampung, 35141, \\ ${ }^{(a)}$ deafaniwahyuardaniswari@gmail.com, ${ }^{(b)}$ josalina7@gmail.com, ${ }^{(c)}$ hana.haritsah@gmail.com, \\ (d) simonsembiring2@gmail.com
}

Diterima (26 September 2019), Direvisi (4 Nopember 2019)

\begin{abstract}
This research was carried out to investigate the effect of asphalt addition to thermal characteristics, functional groups, physical properties (water absorption, water content, and swelling thickness) of rice husk silica. The mass ratio of silica and asphalt alloys were 1:0; 1:0,4; 1:0,5; and 1:0,6. Silica and asphalt were mixed at $160^{\circ} \mathrm{C}$ followed by calcination at $150^{\circ} \mathrm{C}$ for 3 hours. Thermal characteristics and phase structures were analyzed using Differential Thermal Analysis/Thermo Gravimetrical Analysis (DTA/TGA), X-ray Diffraction (XRD), and Fourier Transform Infrared (FTIR). DTA/TGA analysis results show that the addition of asphalt causes a decreasing in mass, on set temperature, maximum temperature, endothermic temperature And an increase in exothermic peak temperature. The results of XRD analysis showed that the addition of asphalt resulted in the appearance of amorphous carbon, shifting the range and the highest intensity of $2 \theta$ amorphous silica. The results of FTIR analysis showed that the addition of asphalt resulted in appearance the functional grups of $\mathrm{C}$-H. The addition of asphalt causes a decrease in the value of water absorption, water content, and swelling thickness.
\end{abstract}

Keywords: asphalt, functional groups, rice husk silica, thermal characteristics.

Abstrak. Penelitian ini dilakukan untuk mengetahui pengaruh penambahan aspal terhadap karakteristik termal, struktur fasa, sifat fisis (daya serap air, kadar air, dan pengembangan tebal) silika sekam padi. Pembuatan paduan silika aspal pada penelitian ini dilakukan dengan menggunakan perbandingan massa silika aspal yaitu 1:0; $1: 0,4 ; 1: 0,5$, dan 1:0,6 pada suhu pencampuran $160^{\circ} \mathrm{C}$ dan dipanaskan pada suhu $150^{\circ} \mathrm{C}$ selama 3 jam. Karakteristik termal dan struktur fasa dianalisis menggunakan Differential Thermal Analysis/Thermo Gravimetrical Analysis (DTA/TGA), X-ray Diffraction (XRD), dan Fourier Transform Infrared (FTIR). Hasil analisis DTA/TGA menunjukkan bahwa penambahan aspal mengakibatkan terjadinya penurunan massa, suhu awal (on set), suhu maksimal dan suhu lembah endotermik. Selain itu, terjadi peningkatan suhu puncak eksotermik. Hasil analisis XRD menunjukkan bahwa penambahan aspal mengakibatkan munculnya karbon amorf, terjadi pergeseran rentang dan intensitas tertinggi $2 \theta$ silika amorf. Hasil analisis FTIR menunjukkan bahwa penambahan aspal mengakibatkan munculnya gugus $\mathrm{C}-\mathrm{H}$. Penambahan aspal mengakibatkan terjadinya penurunan nilai daya serap air, kadar air, dan pengembangan tebal.

Kata kunci: aspal, gugus fungsi, karakteristik termal, silika sekam padi.

\section{PENDAHULUAN}

Komposit merupakan material rekayasa yang banyak dikembangkan dalam bidang ilmu pengetahuan dan teknologi. Komposit memiliki sifat gabungan dari material dasar sehingga didapati sifat material yang lebih unggul pada sifat mekanik, ketahanan kimia, stabilitas terhadap suhu, maupun konduktivitas elektrik [1]. Material rekayasa yang telah banyak digunakan sebagai komposit salah satunya adalah silika. Silika dapat diperoleh dari bahan baku mineral dan nabati. Namun, silika mineral sulit untuk dimurnikan sehingga diperlukan sumber alternatif lain salah satunya silika nabati. Berdasarkan beberapa penelitian, silika nabati dapat diperoleh dari tongkol jagung [2], rumput gajah [3], dan yang paling banyak digunakan adalah sekam padi [4-5]. 
Di dalam sekam padi terdapat kandungan silika yang tinggi yaitu sebesar 94,50\% [6]. Tingginya kandungan silika dalam sekam padi dapat dimanfaatkan sebagai sumber silika. Silika yang diekstraksi dari sekam padi dapat digunakan sebagai bahan baku pembuatan keramik dan komposit [7].

Terdapat dua metode yang digunakan untuk mengekstraksi silika dari sekam padi yaitu metode pengabuan dan metode alkalis. Secara umum metode alkalis didasarkan pada sifat tingginya kelarutan silika dalam basa yang menghasilkan sol sehingga mudah dimanfaatkan menggunakan proses sol gel [8]. Metode alkalis telah banyak digunakan dalam ekstraksi silika dari sekam padi, hal ini dikarenakan prosesnya yang sederhana dan biaya yang murah. Penelitian mengenai ekstraksi silika dari sekam padi menggunakan metode alkalis dan proses sol gel telah dilakukan oleh Simanjuntak dkk., 2016 dan Suka dkk., 2008. Berdasarkan penelitian tersebut secara berturut-turut, memperoleh hasil analisis XRD dan FTIR yang menunjukkan bahwa sampel memiliki struktur amorf dan terdapat gugus $\mathrm{Si}-\mathrm{OH}, \mathrm{Si}-$ O-Si, serta Si-O [8-9].

Sifat amorf dari silika sekam padi menjadikannya memiliki sifat reaktif dengan unsur lain. Keunikan lain dari silika sekam padi berdasarkan sifat fisisnya yaitu memiliki kekerasan dan homogenitas yang tinggi [10]. Silika juga memiliki kerapatan sebesar 2,648 $\mathrm{g} / \mathrm{cm}^{3}$ dan mempunyai stabilitas termal yang tinggi [11], namun sifat lain silika yang mudah berikatan dengan air (hydrophilic) dan porositas yang cukup besar menjadikan silika memiliki daya serap air yang cukup tinggi [12]. Selain itu, silika sekam padi memiliki porositas yang tinggi sehingga dapat dimanfaatkan sebagai pengisi (filler). Dalam komposit, silika berperan sebagai pengisi sedangkan material lainnya merupakan matriks. Matriks yang dapat dipadukan dengan silika adalah aspal.
Aspal terdiri atas senyawa hidrokarbon berwarna gelap atau hitam pekat yang terdiri dari karbon (82-88\%), belerang (0-6\%), oksigen (0-1,5\%), dan nitrogen (0-1\%) [13]. Aspal bersifat termoplastis, jika dipanaskan sampai suhu tertentu aspal dapat menjadi lunak/cair dan jika suhu mulai turun aspal akan mengeras kembali. Sifat termoplastis ini dapat dimanfaatkan sebagai bahan pengikat [14]. Selain itu, menurut Hillstrom dan Ruby (1994) aspal memiliki sifat kedap terhadap air (hydrophobic), tahan terhadap kerusakan dan pembusukan [15]. Berdasarkan sifat yang dimiliki silika maupun aspal, kedua material tersebut ternyata dapat berpotensi menjadi bahan komposit sehingga dapat diperoleh sifat material yang lebih unggul.

\section{METODE PENELITIAN}

\section{Alat dan Bahan}

Alat yang digunakan dalam penelitian ini yaitu gelas ukur, gelas beker, cawan, neraca digital, corong, spatula, mortar dan pastel, alumunium foil, $\mathrm{pH}$ indikator, kertas saring, oven, magnetic stirrer, hot plate, cetakan pelet, pengayak dengan ukuran 150 dan 250 mesh, hydrolic press (Graseby Specac), DTA/TGA (Exstar TG/DTA 7300, XRD (X'Pert PRO PANanlytical), dan FTIR (Nicolet iS10 Spectrometer).

Bahan yang digunakan dalam penelitian ini yaitu sekam padi, larutan natrium hidroksida $(\mathrm{NaOH}) 1,5 \%$, larutan asam nitrat $\left(\mathrm{HNO}_{3}\right) 10 \%$, akuades, aspal penetrasi 60/70, dan bensin.

\section{Ekstraksi Silika Sekam Padi}

Sekam padi terlebih dahulu dibersihkan, dan direndam air selama 1 jam. Sekam padi yang tenggelam diambil dan direndam dengan air panas selama 6 jam, hal ini dimaksudkan untuk menghilangkan kotoran-kotoran (zat organik) yang larut dalam air seperti tanah, pasir, debu, dan zat 
pengotor lain terlepas dari sekam padi. Setelah itu, sekam padi dijemur hingga kering.

Sekam padi hasil preparasi selanjutnya diekstraksi dengan metode ekstraksi alkalis. Sekam padi ditimbang sebanyak 50 gram, kemudian ditambahkan larutan $\mathrm{NaOH}$ 1,5\% sebanyak $500 \mathrm{ml}$. Selanjutnya dipanaskan hinggga mendidih dan didiamkan selama 24 jam dan diperoleh sol silika. Sol silika kemudian ditetesi menggunakan larutan $\mathrm{HNO}_{3} 10 \%$ sebanyak $100 \mathrm{ml}$ hingga menjadi gel silika dengan pH 7. Gel silika yang berwarna kecoklatan, selanjutnya dicuci dengan akuades hangat dan disaring menggunakan kertas saring hingga gel silika berwarna putih. Gel silika kemudian dioven pada suhu $110^{\circ} \mathrm{C}$ selama 3 jam dan diperoleh silika padatan. Silika padatan digerus dengan menggunakan mortar dan pastel hingga menjadi serbuk silika dan berwarna putih. Serbuk silika yang sudah digerus kemudian diayak menggunakan pengayak ukuran 250 mesh untuk mendapatkan serbuk silika dengan ukuran yang homogen.

\section{Pembuatan Paduan Silika Aspal}

Pembuatan paduan silika aspal pada penelitian ini dilakukan dengan menggunakan perbandingan silika aspal yaitu $1: 0 ; 1: 0,4 ; 1: 0,5$ dan 1:0,6. Setelah menimbang aspal sebanyak $2 ; 2,5$; dan 3 gram kemudian dilarutkan dengan bensin sebanyak $30 \mathrm{ml}$ sambil diaduk dan dipanaskan menggunakan hot plate pada suhu $160^{\circ} \mathrm{C}$. Setelah aspal mencair, ditambahkan serbuk silika sebanyak 5 gram dan diaduk dengan spatula hingga homogen sehingga diperoleh serbuk paduan silika aspal.

Paduan silika aspal selanjutnya dipanaskan dengan menggunakan oven selama 3 jam pada suhu $150^{\circ} \mathrm{C}$, kemudian sampel digerus dengan mortar dan pastel. Sampel yang sudah digerus kemudian diayak menggunakan pengayak dengan ukuran 150 mesh untuk mendapatkan serbuk paduan silika aspal dengan ukuran yang homogen. Kode sampel yang digunakan untuk silika sekam padi adalah SA00 dan paduan silika aspal berturut-turut adalah SA04, SA05 dan SA06.

\section{HASIL DAN PEMBAHASAN}

\section{Thermo Gravimetrical Analysis (TGA)}

Gambar 1(a-d) memperlihatkan adanya tiga daerah kehilangan massa dengan rentang suhu tertentu. Pada daerah I dengan rentang suhu $30-300^{\circ} \mathrm{C}$ sampel silika tanpa penambahan aspal mengalami penyusutan massa paling besar seperti ditunjukkan pada Tabel 1 yang mengindikasikan adanya proses penguapan air. Hal ini disebabkan karena sampel tersebut mengalami pemanasan pada suhu $110^{\circ} \mathrm{C}$ selama 3 jam sehingga memungkinkan masih terdapat banyak kandungan air sisa proses ekstraksi sampel.

Pada daerah II dengan rentang suhu $300-450^{\circ} \mathrm{C}$ mengalami penyusutan pada suhu $375^{\circ} \mathrm{C}$ sebesar $0,87 \%$, kemudian turun secara perlahan-lahan sampai suhu $450^{\circ} \mathrm{C}$ dengan penyusutan massa sebesar $0,66 \%$. Pada daerah III dengan rentang suhu 450$600^{\circ} \mathrm{C}$ sampel tidak mengalami penyusutan massa yang signifikan. Hal ini sesuai dengan

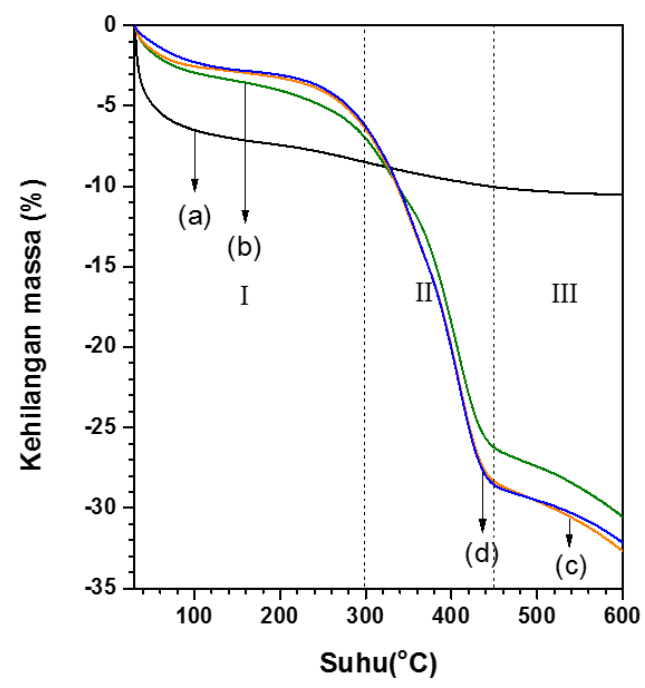


Gambar 1. Grafik TGA sampel (a) SA00 (b) SA04, (c) SA05, dan (d) SA06

Tabel 1. Ringkasan hasil TGA untuk semua sampel
Gambar 2(a-d) memperlihatkan adanya beberapa lembah dan puncak yang mengindikasikan terjadinya proses endotermik dan eksotermik. Grafik DTA untuk sampel SA00 ditunjukkan pada

\begin{tabular}{|c|c|c|c|c|c|c|}
\hline Sampel & $\begin{array}{c}\text { Suhu } \\
\text { mulai } \\
\left({ }^{\circ} \mathrm{C}\right)\end{array}$ & $\begin{array}{c}\text { Suhu } \\
\text { maks } \\
\left({ }^{\circ} \mathrm{C}\right)\end{array}$ & $\begin{array}{c}\text { Susut } \\
\text { massa }(\%) \\
30-300^{\circ} \mathrm{C}\end{array}$ & $\begin{array}{c}\text { Susut } \\
\text { massa }(\%) \\
300-450{ }^{\circ} \mathrm{C}\end{array}$ & $\begin{array}{c}\text { Susut } \\
\text { massa }(\%) \\
450-600^{\circ} \mathrm{C}\end{array}$ & $\begin{array}{c}\text { Residu (\%) } \\
600{ }^{\circ} \mathrm{C}\end{array}$ \\
\hline SA00 & 100 & 494 & 8,51 & 1,53 & 0,48 & 89,48 \\
\hline SA04 & 80 & 445 & 7,03 & 19,22 & 4,32 & 69,43 \\
\hline SA05 & 72 & 442 & 6,48 & 21,88 & 4,27 & 67,31 \\
\hline SA06 & 64 & 438 & 6,29 & 22,29 & 3,59 & 67,83 \\
\hline
\end{tabular}

hasil penelitian yang memperoleh silika sekam padi yang memiliki stabilitas termal yang tinggi [11].

Grafik TGA untuk sampel SA00, SA04, SA05, dan SA06 ditunjukkan pada Gambar 1(b-d). Pada daerah I dengan rentang suhu 30-300 ${ }^{\circ} \mathrm{C}$ sampel SA04, SA 05, dan SA06 mengalami penyusutan massa dengan persentase lebih rendah dari pada sampel SA00 ditunjukkan pada Tabel 1, hal ini mengindikasikan adanya proses penguapan air dan senyawa volatil asphaltene. Sampel silika dengan penambahan aspal mengalami sedikit penyusutan massa disebabkan karena sampel tersebut telah melalui proses pemanasan pada suhu $150^{\circ} \mathrm{C}$ selama 3 jam sehingga memungkinkan kandungan air dalam sampel sudah berkurang. Pada daerah II dengan rentang suhu $300-450^{\circ} \mathrm{C}$ sampel mengalami penyusutan massa secara drastis hingga $21 \%$ yang mengindikasikan adanya proses penguapan lebih lanjut senyawa volatil dan dekomposisi asphaltene. Pada daerah III dengan rentang suhu $450-600^{\circ} \mathrm{C}$ mengalami penyusutan massa secara perlahan-lahan yang mengindikasikan bahwa sampel menuju keadaan stabil. Hal ini berarti bahwa partikel silika dan aspal tercampur secara homogen [16].

\section{Differential Thermal Analysis (DTA)}

Gambar 2(a). Pada rentang suhu $30-200^{\circ} \mathrm{C}$

ditemukan kehadiran lembah endotermik pada suhu $140^{\circ} \mathrm{C}$ yang mengindikasikan terjadinya proses penguapan air dan senyawa volatil pada sampel. Pada rentang suhu $300-450^{\circ} \mathrm{C}$ ditemukan kehadiran puncak eksotermik pada suhu $354^{\circ} \mathrm{C}$ yang mengindikasikan terjadinya dekomposisi silika menghasilkan ikatan $\mathrm{Si}-\mathrm{OH}$ atau silanol. Ikatan tersebut terjadi akibat interaksi antara silika dengan air [6].

Grafik DTA untuk sampel SA04, SA05, dan SA06 ditunjukkan pada Gambar 2(b-d). Pada rentang suhu $30-200^{\circ} \mathrm{C}$ ditemukan kehadiran lembah endotermik yang mengindikasikan terjadinya proses penguapan molekul asphaltene dan senyawa volatil pada sampel. Pada rentang suhu 300$450^{\circ} \mathrm{C}$ terdapat kehadiran puncak 


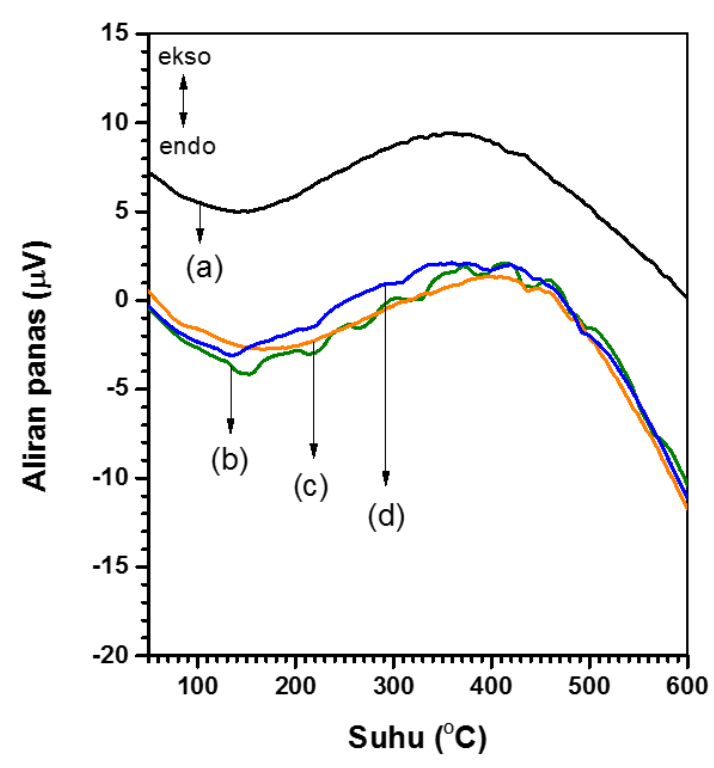

Gambar 2. Grafik DTA sampel (a) SA00, (b) SA04, (c) SA05, dan (d) SA06

eksotermik secara berturut-turut pada suhu 408,398 , dan $368^{\circ} \mathrm{C}$ yang mengindikasikan terjadinya dekomposisi aspal yang kemudian menghasilkan ikatan $\mathrm{C}=\mathrm{O}$ atau karbonil dan ikatan C-H. Hal ini disebabkan oleh interaksi antara molekul $\mathrm{H}$ dan $\mathrm{O}$ dari air pada silika dengan molekul $\mathrm{C}$ pada aspal [16].

\section{X-Ray Diffraction (XRD)}

Karakterisasi XRD dilakukan untuk mengetahui struktur yang terbentuk dari sampel. Difraktogram sampel SA00 ditunjukkan pada Gambar 3(a) yang memperlihatkan adanya pola difraksi yang lebar pada rentang $2 \theta=19-25^{\circ}$ dengan intensitas tertinggi sekitar $2 \theta=22^{\circ}$, sesuai dengan penelitian sebelumnya. Adanya pola difraksi yang lebar pada sampel SA00 menunjukkan bahwa struktur yang terbentuk adalah amorf.

Difraktogram untuk sampel SA04, SA05, dan SA06 secara berturut-turut ditunjukkan pada Gambar 3(b-d). Hasil analisis memperlihatkan bahwa struktur yang terbentuk adalah amorf yang ditandai dengan adanya pola difraksi yang lebar pada rentang $2 \theta=19-24^{\circ}$. Di antara rentang tersebut terdapat $2 \theta$ dengan intensitas tertinggi sekitar $21^{\circ}$ yang teridentifikasi sebagai silika dan $2 \theta=20^{\circ}$ yang

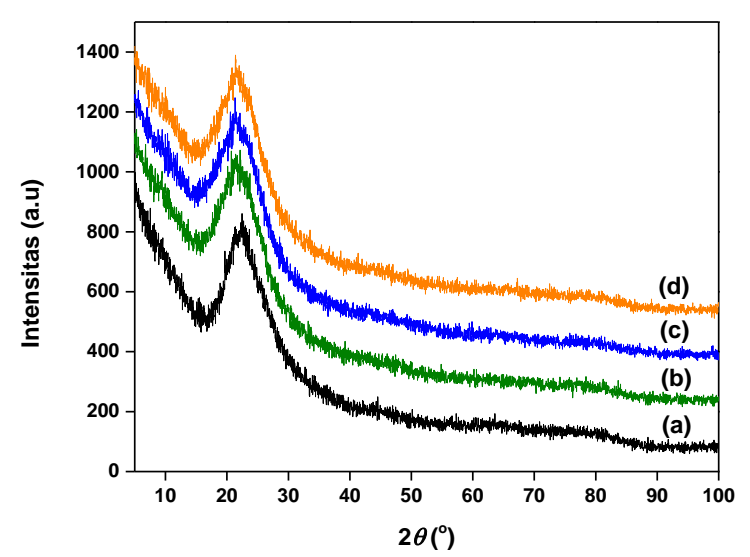

Gambar 3. Difraktogram sampel (a) SA00, (b) SA04, (c) SA05, dan (d) SA06.

teridentifikasi sebagai karbon sekitar $2 \theta=$ $20^{\circ}$. Alizadeh dan Modarres (2019) memperoleh bahwa aspal yang diuji XRD mempunyai pola difraksi yang lebar dengan intensitas tertinggi sekitar $2 \theta=20^{\circ}$ teridentifikasi sebagai karbon [17]. Adanya penambahan aspal mengakibatkan teridentifikasinya karbon amorf dan terjadi pergeseran $2 \theta$ intensitas tertinggi silika dari $22^{\circ}$ menjadi $21^{\circ}$.

\section{Fourier Transform Infrared (FTIR)}

Hasil pengujian FTIR dari sampel SA00, SA04, SA05, dan SA06 seperti yang ditunjukkan pada Gambar 4(a-d). Grafik spektrum FTIR dari sampel SA00 yang ditunjukkan pada Gambar 4(a) terdapat puncak serapan pada bilangan gelombang $3448,72 \mathrm{~cm}^{-1}$ yang menunjukkan vibrasi ulur gugus hidroksil $(\mathrm{O}-\mathrm{H})$ yang berikatan dengan logam Si membentuk ikatan silanol (Si-OH) [18-19]. Munculnya gugus $\mathrm{Si}-\mathrm{OH}$ mengindikasikan telah terjadi penyerapan molekul air pada permukaan silika. Adanya molekul air dalam sampel juga diperkuat dengan munculnya puncak serapan pada bilangan gelombang $1635,64 \mathrm{~cm}^{-1}$ yang 


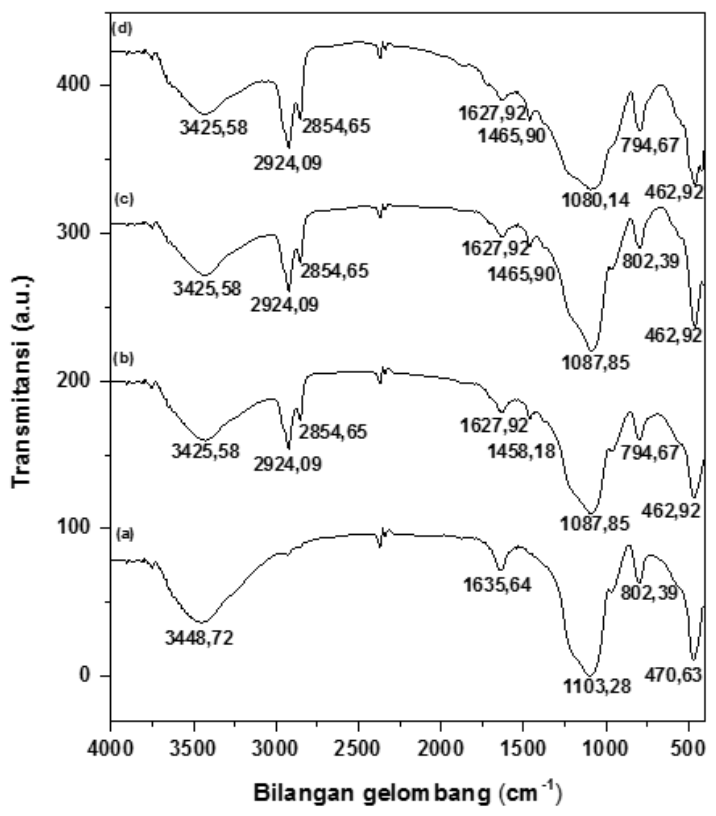

Gambar 4. Spektrum FTIR sampel (a) SA00, (b) SA04, (c) SA05, (d) SA06

Tabel 2. Puncak serapan gugus fungsi silika sekam padi serta paduan silika sekam padi dan aspal

\begin{tabular}{ccccc}
\hline Gugus Fungsi & SA00 $\left(\mathrm{cm}^{-1}\right)$ & SA04 $\left(\mathrm{cm}^{-1}\right)$ & SA05 $\left(\mathrm{cm}^{-1}\right)$ & SA06 $\left(\mathrm{cm}^{-1}\right)$ \\
\hline Si-OH & 3448,72 & 3425,58 & 3425,58 & 3425,58 \\
C-H & - & 2924,09 & 2924,09 & 2924,09 \\
C-H & - & 2854,65 & 2854,65 & 2854,65 \\
O-H & 1635,64 & 1627,92 & 1627,92 & 1627,92 \\
C-H & - & 1458,18 & 1465,90 & 1465,90 \\
Si-O-Si & 1103,28 & 1087,85 & 1087,85 & 1087,85 \\
Si-O & 802,39 & 794,67 & 786,96 & 802,39 \\
Si-O & 470,63 & 462,92 & 470,63 & 462,92 \\
\hline
\end{tabular}

merupakan vibrasi tekuk gugus O-H [2021]. Selanjutnya muncul puncak serapan pada bilangan gelombang $1103,28 \mathrm{~cm}^{-1}$ yang mengindikasikan adanya vibrasi ulur gugus siloksan (Si-O-Si) [19-20]. Keberadaan gugus $\mathrm{Si}-\mathrm{O}-\mathrm{Si}$ diperkuat dengan adanya puncak serapan pada bilangan gelombang 802,39 dan $470,63 \mathrm{~cm}^{-1}$ yang menunjukkan adanya vibrasi ulur dan tekuk gugus siloksi (Si-O) yang sesuai dengan penelitian Adam dkk., (2006) [18] dan Geetha dkk., (2016) [19].

Berdasarkan Gambar 4(a-d), puncak serapan yang terkait dengan sampel SA00 yang juga muncul pada sampel SA04, SA05, dan SA06 yaitu pada bilangan gelombang 3448,$72 ; 1635,64 ; 1103,28 ; 802,39$; dan
$470,63 \mathrm{~cm}^{-1}$. Masing-masing bilangan gelombang tersebut secara berturut-turut menunjukkan adanya vibrasi gugus $\mathrm{Si}-\mathrm{OH}$, O-H, Si-O-Si, dan Si-O. Selain itu muncul beberapa puncak serapan baru yang sebelumnya tidak ada pada sampel SA0 yaitu pada bilangan gelombang 2924,09; 2854,65; dan 1458,18 $\mathrm{cm}^{-1}$. Puncak serapan pada bilangan gelombang 2924,09 dan $2854,65 \mathrm{~cm}^{-1}$ menunjukkan adanya vibrasi ulur gugus $\mathrm{C}-\mathrm{H}$ sesuai dengan penelitian Jiang dkk., (2017) [22]. Keberadaan gugus $\mathrm{C}-\mathrm{H}$ juga didukung dengan adanya puncak serapan pada bilangan gelombang 1458,18 $\mathrm{cm}^{-1}$ yang mengindikasikan adanya vibrasi ulur gugus $\mathrm{C}-\mathrm{H}$, sesuai dengan penelitian sebelumnya [23-24]. Terbentuknya gugus 
C-H mengindikasikan sebagai gugus utama pembentukan aspal di dalam sampel.

Berdasarkan Gambar 4(a-d) juga terlihat bahwa dengan adanya penambahan aspal mengakibatkan terjadinya pergeseran puncak serapan. Pergeseran puncak serapan ini diduga karena telah terjadi interaksi antar gugus fungsi dari silika dengan aspal [25]. Secara lebih terperinci berbagai puncak serapan yang terdeteksi pada masing-masing sampel disajikan pada Tabel 2. Dengan hadirnya puncak serapan yang menandakan gugus fungsi $\mathrm{Si}-\mathrm{OH}, \mathrm{O}-\mathrm{H}, \mathrm{Si}-\mathrm{O}-\mathrm{Si}$, dan $\mathrm{Si}-\mathrm{O}$ dari silika dan C-H dari aspal pada sampel SA04, SA05, dan SA06 mengindikasikan bahwa sampel telah tercampur namun tidak

dengan $m_{\mathrm{b}}$ adalah massa sampel setelah direndam akuades $(\mathrm{g})$ dan $m_{\mathrm{k}}$ adalah massa sampel sebelum direndam akuades $(\mathrm{g})$.

Hasil analisis menunjukkan bahwa terjadi penurunan yang drastis dari sampel SA00 hingga sampel SA04 sekitar 23\%, kemudian turun secara perlahan sekitar 1,3\% pada sampel SA05, dan $0,2 \%$ pada sampel SA06. Sampel SA00 memiliki nilai daya serap air paling tinggi, hal ini disebabkan karena silika sekam padi memiliki karakteristik yaitu mudah berikatan dengan air (hydrofilic). Selain itu, silika sekam padi memiliki porositas yang tinggi sehingga memungkinkan air mudah masuk melalui pori-porinya.

Sampel SA04, SA05, dan SA06 mengalami penurunan nilai daya serap air secara perlahan-lahan yang mengindikasikan bahwa aspal telah mengikat silika sekam padi dan menutup pori pada permukaan sampel sehingga tidak mampu mengikat lebih banyak molekul air. Hal ini sesuai dengan karakteristik yang dimiliki oleh aspal yaitu bersifat termoplastis [14] dan kedap terhadap air [15] terjadi reaksi kimia antara silika dengan aspal

\section{Daya Serap Air}

Pengujian daya serap air didasarkan pada ASTM C-20-00-2005 dengan melakukan perendaman dalam akuades selama 3 jam dan dilakukan pada semua sampel yaitu SA00, SA04, SA05, dan SA06. Perhitungan nilai daya serap air menggunakan Persamaan 1. Hasil uji daya serap air ditunjukkan pada Gambar 5.

Daya serap air $(\%)=\left(\frac{m_{b}-m_{k}}{m_{k}}\right) \times 100 \%$

yang menyebabkan nilai daya serap air menurun.

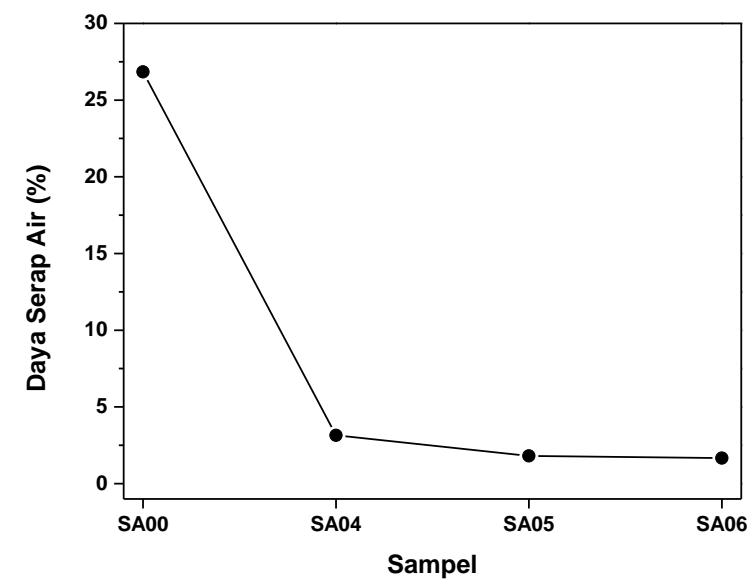

Gambar 5. Grafik hasil uji daya serap air.

\section{Kadar Air}

Pengujian kadar air dilakukan berdasarkan SNI 03-1971-1990, yang dilakukan dengan menimbang massa sampel sebelum dipanaskan dan setelah dipanaskan 
pada suhu $110^{\circ} \mathrm{C}$. Untuk memperoleh persen kadar air sampel dilakukan perhitungan menggunakan Persamaan 2 dan diperoleh hasil uji kadar seperti yang ditunjukkan pada Gambar 6.

$$
\operatorname{Kadar} \operatorname{air}(\%)=\left(\frac{m_{3}-m_{5}}{m_{5}}\right) \times 100 \%
$$

dengan $m_{3}$ adalah massa sampel sebelum dipanaskan (g) dan $m_{5}$ adalah massa sampel setelah dipanaskan $(\mathrm{g})$.

Hasil uji kadar air yang ditunjukkan pada Gambar 6, terlihat bahwa terjadi penurunan drastis dari sampel SA00 ke SA04. Penurunan ini disebabkan adanya penambahan aspal yang bersifat hidropobik sehingga sifat adsorpsi yang dimiliki silika akan menurun. Seiring dengan penambahan aspal di dalam sampel menunjukkan bahwa penurunan kadar air terjadi secara perlahanlahan dari $4,164 \%$ pada sampel SA04 sampai 2,398 \% pada sampel SA06.

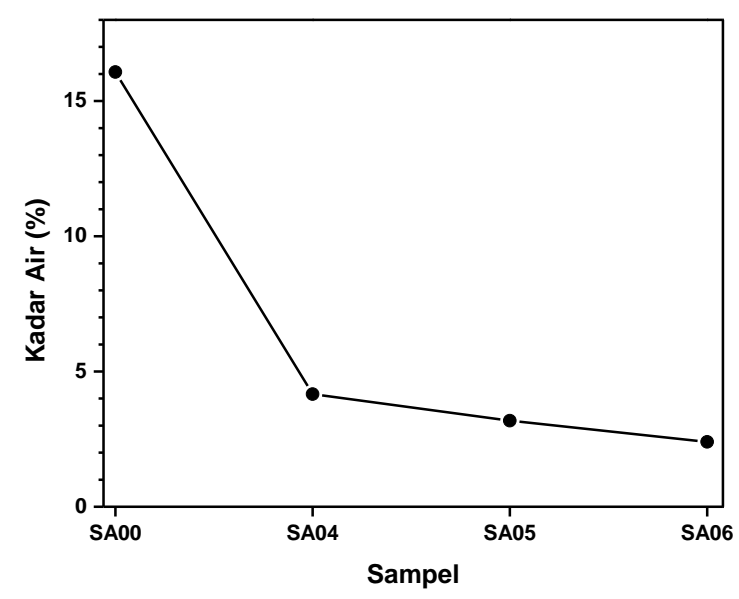

Gambar 6. Grafik hasil uji kadar air.

\section{Pengembangan Tebal}

Uji pengembangan tebal dilakukan berdasarkan SNI 03-2105-2006. Perhitungan pengembangan tebal menggunakan Persamaan 3 dan diperoleh hasil uji pengembangan tebal seperti yang ditunjukkan pada Gambar 7.

Pengembangan tebal $(\%)=\left(\frac{d_{1}-d_{0}}{d_{0}}\right) \times 100 \%$

dengan $d_{\mathrm{o}}$ adalah tebal sampel sebelum direndam akuades $(\mathrm{mm})$ dan $d_{1}$ adalah tebal sampel setelah direndam akuades ( $\mathrm{mm}$ ).

Gambar 7 menunjukkan bahwa pengembangan tebal mengalami penurunan dari $0,362 \%$ pada sampel SA00 menjadi $0,203 \%$ pada sampel SA06. Penurunan ini disebabkan oleh adanya penambahan aspal yang bersifat hidropobik sebagai bahan yang masuk ke dalam pori-pori silika sehingga pori-pori silika akan tertutupi oleh aspal dan mengakibatkan air yang terserap oleh sampel semakin sedikit. Selain itu, penurunan pengembangan tebal yang dihasilkan tidak signifikan dari sampel SA00 sampai SA06. Hal ini disebabkan oleh silika yang bersifat tidak larut dalam air sudah diikat oleh aspal yang bersifat kedap terhadap air dan viskoelastis sehingga menyebabkan nilai pengembangan tebal yang dihasilkan mengalami penurunan yang tidak signifikan.

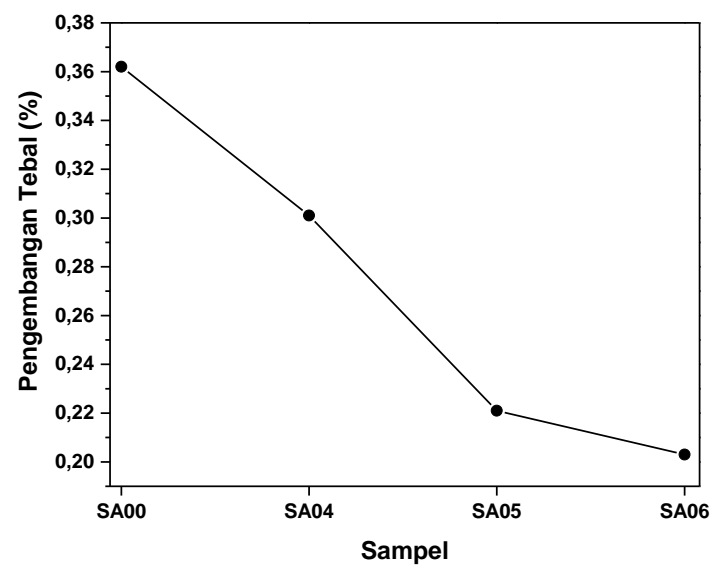

Gambar 7. Grafik hasil uji pengembangan tebal.

\section{KESIMPULAN}

Berdasarkan hasil penelitian maka dapat disimpulkan bahwa penambahan aspal terhadap silika sekam padi menurut hasil 
analisis TGA menunjukkan terjadinya penurunan massa, suhu mulai (on set) dan suhu maksimal yang berarti bahwa sampel mengalami penurunan stabilitas termal. Hasil analisis DTA menunjukkan terjadinya penurunan suhu lembah endotermik yang berarti bahwa sampel lebih mudah melepaskan molekul air. Selain itu, seiring dengan penambahan aspal terjadi peningkatan suhu puncak eksotermik yang berarti bahwa sampel semakin sulit melepaskan panas. Hasil analisis XRD menunjukkan struktur yang sama yaitu amorf. Penambahan aspal mengakibatkan teridentifikasi adanya karbon pada $2 \theta=20^{\circ}$ dan terjadi pergeseran $2 \theta$ intensitas tertinggi silika dari $22^{\circ}$ menjadi $21^{\circ}$. Hasil analisis FTIR menunjukkan bahwa penambahan aspal menyebabkan hadirnya gugus fungsi baru yaitu C-H. Selain itu, penambahan aspal mengakibatkan penurunan nilai daya serap air, kadar air, dan pengembangan tebal.

\section{DAFTAR PUSTAKA}

[1] C. Liza, Nanokomposit Polipropilen Clay. Tangerang: Majalah Sentra Polimer, 2009.

[2] K. Mohanraj, S. Kannan, S. Barathan, G. Sivakumar, and C. Instrumentation, "Preparation and characterization of nano $\mathrm{SiO} 2$ from corn cob ash by precipitation method," vol. 6, no. 3, pp. 394-397, 2012.

[3] I. Issaharou-matchi, D. Barboni, J. Meunier, M. Saadou, and P. Dussouillez, "Intraspecific biogenic silica variations in the grass species Pennisetum pedicellatum along an evapotranspiration gradient in South Niger," Flora, vol. 220, pp. 84-93, 2016.

[4] S. Chandrasekhar, P. N. Pramada, P. Raghavan, and K. G. Satyanarayana, "Microsilica from rice husk as a possible substitute for condensed silica fume for high performance concrete," pp. 1245-1247, 2002.

[5] U. Kalapathy, A. Proctor, and J. Shultz, "A simple method for production of pure silica from rice hull ash," vol. 73, 2000.

[6] A. A. M. Daifullah, B. S. Girgis, and H. M. H. Gad, "Utilization of agroresidues ( rice husk ) in small waste water treatment plans," vol. 57, pp. 1723-1731, 2003.

[7] W. Simanjuntak, S. Sembiring, D. Pandiangan, F. Syani, and T. M. Situmeang, "The use of liquid smoke as a substitute for nitric acid for extraction of amorphous silica from rice husk through sol-gel route," vol. 32, no. 4, pp. 2079-2085, 2016.

[8] S. Sembiring and W. Simanjuntak, Silika Sekam Padi Potensinya sebagai Bahan Baku Keramik Industri. Yogyakarta: Plantaxia, 2015.

[9] I. G. Suka, W. Simanjuntak, S. Sembiring, and E. Trisnawati, "Karakteristik silika sekam padi dari provinsi lampung yang diperoleh dengan metode ekstraksi," vol. 37, no. 1, pp. 47-52, 2008.

[10] C. J. Brinker and G. W. Scherer, Sol Gel Science The Physics and Chemistry of Sol Gel Processing. USA: Academic Press, 1990.

[11] P. K. Malik, "Used of activated carbons prepared from saw dust and rice husk for adsorption of acid dyes : a case of acid yellow," Dye. Pigment, vol. 56, pp. 239-249, 2002.

[12] S. Sembiring and P. Karo Karo, "Pengaruh suhu sintering terhadap karakteristik termal dan mikrostruktur silika sekam padi," vol. 13, no. 3, pp. 233-239, 2007.

[13] J. Read and D. Whiteoak, The Shell Bitumen Hand Book, Fifth. London: Thomas Telford, 2003. 
[14] S. Sukirman, Beton Aspal Campuran Panas. Jakarta: Granit, 2003.

[15] K. Hillstrom and K. R. Marry, "Encyclopedia of American Industries," Biosyst. Eng., vol. 1, pp. 15-28, 1994.

[16] S. Sembiring, A. Riyanto, R. Situmeang, and Z. Sembiring, "Bituminous composite comprising amorphous silica," vol. 63, no. 3, pp. 277-286, 2019.

[17] A. Alizadeh and A. Modarres, "Mechanical and microstructural study of rap - clay composites containing bitumen emulsion and lime," vol. 31, no. 2, pp. 1-14, 2019.

[18] F. Adam, K. Kandasamy, and S. Balakrishnan, "Iron incorporated heterogeneous catalyst from rice husk ash," J. Colloid Interface Sci., vol. 304, no. 1, pp. 137-143, 2006.

[19] D. Geetha, A. Ananthiand, and P. S. Ramesh, "Applied Physics," Prep. Charact. silica Mater. from rice husk ash-an Econ. viable method, vol. 4, no. 3, pp. 20-26, 2016.

[20] M. Dominic and A. Jose, "Rice husk silica-efficient biofillerin high density polyethylene," International Journal Advance Scientific and Technical Research., vol. 2, no. 4, pp. 561-569, 2017.

[21] S. Musić, N. F. Vinceković, and L.
Sekovanić, "Precipitation of amorphous sio 2 particles and their properties," Brazilian J. Chem. Eng., vol. 28, no. 01, pp. 89-94, 2011.

[22] Z. Jiang, X. Zheng, and S. M. Easa, "Evaluation of physical, rheological, and structural properties of vulcanized evaluation of physical, rheological, and structural properties of vulcanized EVA / SBS modified bitumen," Journal of Applied

Polymer Science, vol. 13, no. 21, pp. 1-10, 2017.

[23] S. I. Ali, A. Ismail, M. R. Karim, I. N. Yusoff, A. R. Al-Mansob, and E. Aburkaba, "Performance evaluation of $\mathrm{Al}_{2} \mathrm{O}_{3}$ nanoparticle- modified asphalt binder," Road Mater. Pavement Des., vol. 18, no. 6, pp. 1251-1268, 2016.

[24] F. Chi and Z. Liu, "Qualitative analysis of SBS modifier in asphalt pavements using field samples," IOP Conf. Ser. Mater. Sci. Eng., vol. 207, no. 1, pp. 1-6, 2017.

[25] A. I. Putri, A. Sundaryono, and I. N. Candra, "Karakterisasi nanopartikel kitosan ekstrak daun ubijalar ( ipomoea batatas 1.) menggunakan metode gelasi ionik," Alotrop: Jurnal Pendidikan dan Ilmu Kimia, vol. 2, no. 2, pp. 203-207, 2018. 